\title{
Detection and sequence analysis of grapevine virus B isolates from China
}

\author{
G. J. HU, Y. F. DONG*, Z. P. ZHANG, X. D. FAN, R. FANG, H. J. ZHU \\ National Center for Eliminating Viruses from Deciduous Fruit Tree, Research Institute of Pomology, Chinese Academy of Agriculture \\ Sciences, Xingcheng, Liaoning 125100, P. R. China \\ Received September 16, 2013; accepted May 15, 2014

\begin{abstract}
Summary. - The presence of grapevine virus B (GVB) was detected in 188 grapevine samples from China by double antibody sandwich ELISA (DAS-ELISA) and reverse transcription-PCR (RT-PCR). The accuracy of detection by RT-PCR was confirmed by sequencing amplified PCR fragments. Seventeen samples were GVBpositive by DAS-ELISA and five by RT-PCR. The isolate QMW proved to be positive by RT-PCR only, and four isolates (DGWH, DGW, QM, and JFL) could be detected by both methods. Among the five GVB-positive samples detected by RT-PCR, two isolates were originally collected from Henan province and three from Liaoning province. The expected 722 bp DNA fragment, covering partial ORF3 through partial ORF5, was amplified from the five GVB infected samples. Sequence analysis revealed that the molecular variants' composition of GVB in the different isolates was complex. Clones of DGWH, DGW, QM, and JFL isolate shared high nucleotide identities, while the identities among the clones of isolate QMW varied. The variants of GVB isolates obtained in this study showed nucleotide identities from $81.1 \%$ to $97.9 \%$ among themselves, and $79.1 \%$ to $98.5 \%$ identity with five previously published GVB isolates in NCBI. The alignment of partial ORF3 and the phylogenetic relationships of ORF4 revealed that the molecular variants of Chinese GVB isolates could be clustered into three groups. Only isolate DGW was in the same group with the reported GVB isolates from other countries; the other four GVB isolates in this study were clustered into two groups.
\end{abstract}

Keywords: GVB; detection; sequence alignment; phylogeny

\section{Introduction}

Rugose wood (RW) is a complex of graft transmissible grapevine diseases that may cause modifications of the woody cylinder. Four disorders are associated with RW, which can be separately identified through biological indexing. Corky bark (CB) disorder was first described in 1954 (Hewitt, 1954) and is thought to involve members of the family Flexiviridae (Boscia et al., 1993). Although, technically, it is currently impossible to fulfill all Koch's postulates regarding a definitive role for grapevine virus $B(G V B)$ in

"Corresponding author: E-mail: yfdong@163.com; phone: +86429-3598278.

Abbreviations: $\mathrm{CB}=$ corky bark; $\mathrm{CP}=$ coat protein; DAS-ELISA = double antibody sandwich ELISA; GVA = grapevine virus $\mathrm{A} ; \mathrm{GVB}$ = grapevine virus $\mathrm{B}$; IR = intergenic region; $\mathrm{RT}$ $\mathrm{PCR}=$ reverse transcription $-\mathrm{PCR} ; \mathrm{RW}=$ the rugose wood
$\mathrm{CB}$ disease, but the clear association of this virus with $\mathrm{CB}$ affected LN33 hybrid grapevines strongly suggests that GVB causes CB (Boscia et al., 1997). GVB is transmitted between grapevines by several species of the pseudococcid mealybugs of the genera Pseudococcus and Planococcus (Engelbrecht and Kasdorf, 1990; Golino et al., 1995). GVB can be inoculated from grapevines to Nicotiana species mechanically or by insect vectors (Boscia et al., 1997; Garau et al., 1995) and can also be acquired through Cuscuta spp. (dodder) (Garau et al., 1993).

GVB is a member of the Vitivirus genus (Komínek et al., 2009). Its particles are elongated, phloem-associated and flexuous. The genome contains a single-stranded RNA of $7599 \mathrm{bp}$, excluding the poly A tail at the 3 ' terminus, comprising five open reading frames (ORF1-5) (Saldarelli et al., 1996; Saldarelli et al., 2000; Moskovitz et al., 2008). ORF1 encodes a $194 \mathrm{kDa}$ replication-associated protein. The function of the $20 \mathrm{kDa}$ protein encoded by ORF2 is not known. ORF3 
is a putative movement protein (MP) gene, which induces tubule-like and punctate structures during virus infection and is localized to the plasmodesmata (Haviv et al., 2012). ORF4 encodes the coat protein (CP). ORF5 encodes a putative RNA binding protein ( $\mathrm{RNbP}$ ). The corresponding ORF5 product of GVA, the type member of Vitiviruses serologically related to GVB (Komínek et al., 2009), was postulated to possess RNA silencing suppressor activity (Chiba et al., 2006; Zhou et al., 2006). There is a unique intergenic region (IR) between ORFs 4 and 5, which may act as a promoter for ORF5 (Shi et al., 2004). Some studies have demonstrated that the GVB genome is extensively variable (Shi et al., 2004; Sciancalepore et al., 2006). The amino acid (aa) sequences of all ORFs, except for ORF4, contained highly divergent regions (Goszczynski, 2010). Although GVB has been detected in China for 10 years (Liu et al., 2004; Liu and Wang, 2004), sequence data of present isolates are lacking. The aims of this study were to detect the occurrence of GVB in Chinese grapevine cultivars and analyze the genomic variability of the virus.

\section{Materials and Methods}

The woody canes of samples were collected from a vineyard, established in 2010, in the Research Institute of Pomology, Chinese Academy of Agriculture Sciences, during the autumn of 2011 and 2012. The names of the cultivars could not be recorded because they were originally gathered from different areas of China where they are named differently. A half of the cane of each sample was analyzed by DAS-ELISA testing and the other half was detected by RT-PCR. An anti-GVB polyclonal antibody (Agritest srl, Italy) and its alkaline phosphatase conjugate were used in DAS-ELISA, and the threshold for detection was twice the absorbance of the three replicates of the healthy control.

Total RNA was extracted using a silica-based method according to Foissac et al. (2001). The first-strand cDNAs were generated by reverse transcription reactions with random hexamer primers, and subjected to a PCR reaction with GVB-specific primers GVB-F (5' -GTGTACGAGACAATAAGCAAGCA -3') and GVB-R ( $5^{\prime}$-GTAGCCCTTCGTTTAGCCGCACT-3'), which corresponded to nucleotides (nt) 6408-6431 and 7106-7129 of GVB, respectively, and covered partial ORF3, ORF4, the IR and ORF5. Thermocycling parameters consisted of a single cycle of $3 \mathrm{~min}$ at $94^{\circ} \mathrm{C}$; followed by 35 cycles of $30 \mathrm{sec}$ at $94^{\circ} \mathrm{C}, 30 \mathrm{sec}$ at $55^{\circ} \mathrm{C}$, $45 \mathrm{sec}$ at $72^{\circ} \mathrm{C}$; and a final extension for $10 \mathrm{~min}$ at $72^{\circ} \mathrm{C}$. Amplification was conducted in a 96-well PCR Thermal Cycler (Model PTC200, MJ Research, USA). PCR products were separated by electrophoresis in $1.2 \%$ agarose gel, stained with $0.5 \mu \mathrm{g} / \mathrm{ml}$ of ethidium bromide and visualized under UV light. The PCR products were gel-purified and ligated into the pMD18-T vector (TaKaRa, China) according to the manufacturer's instructions. The recombinant plasmids were transformed into Escherichia coli DH5a. One GVB isolate from Italy, inoculated in N. benthamiana, was also cloned, and named G-B. Three independent positive clones of each isolate were sequenced in both directions. The obtained virus-specific sequences were compared with all reported isolates available in GenBank (http://www.ncbi.nlm.nih.gov). Sequence analysis was performed using the DNAMAN 5.2.2. Multiple sequence alignment was performed using the Clustal X 1.8 program. The phylogenetic tree was derived by importing the aligned sequences (produced with Clustal X 1.8) into MEGA 4.1 and constructed using the neighbor-joining method with 1,000 bootstrap replicates.

\section{Results and Discussion}

GVB was detected in 17 samples out of 188 by DASELISA. Only five GVB-positive samples were acquired by RT-PCR. Among the five isolates, DGWH and DGW were originally collected from Henan province, and QM, JFL, and QMW were from Liaoning province. Isolate QMW proved to be positive only by RT-PCR, and four isolates (DGWH, DGW, QM, and JFL) could be detected by both methods. The infection rate of GVB is limited by certain factors. GVB displays a complex infection pattern; it is usually accompanied by other viruses of the Vitivirus genus, such as GVA and the yields in grapevine are low (Komínek et al., 2009). In addition the presence of PCR-inhibitory compounds in the host, such as polyphenols, tannins, and polysaccharides, may also inhibit virus detection (Radaelli et al., 2008). GVB is poorly immunogenic (Boscia et al., 1993); therefore, the production of high-quality virus-specific antibodies suitable for the large-scale detection of GVB is difficult. Moreover, researchers have demonstrated that this virus is extensively variable (Shi et al., 2004; Sciancalepore et al., 2006), which also affects the detection rate.

The PCR products of the GVB isolates were cloned and sequenced. Sequence analysis showed that the identities among the clones of each isolate of DGWH, DGW, QM, and JFL were very high, up to $99.0 \%$. By contrast, the clones of isolate QMW showed identities of 96.7-98.9\% and G-B showed identities $97.5-99.3 \%$. To verify the variants of each isolate further, clones of the isolates were sequenced. Alignments using the new sequences showed that five clones of isolates DGWH, DGW, QM, and JFL also shared high nt identities. One newly sequenced clone of isolate DGWH and two clones of isolate DGW had $100 \%$ nt identities with the previous clones. The nt identities among the clones of isolate QMW and G-B were noticeably lower: up to 96.4-99.7\% and $82.3-99.7 \%$, respectively. A clone of QMW showing insertions and deletions of nucleotides was not included. The alignment result demonstrated that the composition of sequence variants of GVB in different isolates was complex. It is interesting that isolate G-B, which was passaged in $N$. benthamiana for more than 10 years, comprised several se- 
quence variants. Magome et al. (1999) found that serial passages of apple stem grooving virus, a member of Flexiviridae, in indicator plants resulted in the predominance of a specific sequence variants by selective multiplication.

The sequence identities among the variants of six GVB isolates (including G-B) obtained in this study varied from $81.1 \%$ to $97.9 \%$ at nt level, and they shared $79.1 \%$ to $98.5 \%$ nt identities with five previously documented GVB isolates from different countries (Table 1). Sequencing data showed that the amplified fragment ranged from partial ORF3 to partial ORF5. The variations at both the nt and aa levels in each region among all the isolates identified in this study as well as some documented isolates were calculated (Table 1 and Fig. 1). The IR showed higher nucleotide sequence variability than the other regions, which was similar to a previous result (Shi et al., 2004). Among the coding regions, ORF3 varied the most at the aa level. The alignment of the highly divergent aa sequence in ORF3 (6444-6522 nt) (Goszczynski, 2010) showed that the sequences obtained in this study contained many aa substitutions compared with the previously reported GVB isolates. The variants of the six isolates showed relatively distant genetic relationships with the documented GVB isolates (Acc. Nos EF583906 (South African), GU733707 (South African) and JX513897 (USA)). In this study, all GVB isolates with four significant aa substitutions were classified into four groups: Group I, Group II, Group III and Group IV. The sequences in Groups II-IV shared $52.6 \%$ to $76.3 \%$ nt identities with Group I. Sequence variants from isolate DGW were clustered into Group II together with the Italian isolates G-B and X75448, as well as a South African isolate (GU984638). Isolate DGWH and JFL from Liaoning province were in Group III, and G-B-6, a variant of isolate $\mathrm{G}-\mathrm{B}$ shared the same amino acids with variants within this group. The isolates QM and QMW from Henan province were in Group IV (Fig. 1a). The nt and aa identities of CP among the variants of isolates from China and previously reported GVB isolates were $77.4 \%$ to $98.3 \%$ and $88.8 \%$ to $99.0 \%$, respectively. Phylogenetic analysis of aa sequence of CP showed a similar grouping as ORF3 (Fig. 1b). The sequence analysis results revealed that GVB in China showed some phylogenetic correlation between isolates and the geographical regions of hosts compared with other countries.

The extensive vegetative propagation of grapevine and grafting practices may explain the presence of extensive sequence variation in the GVB RNA (Shi et al., 2004), which may also have affected the detection efficiency of the virus. The obtained sequence data showed variability of coat protein genes among GVB isolates from distinct geographical regions of China. The available nucleotide sequences of GVB, associated with the application of the latest developments in molecular biology techniques, e.g. real-time RT-PCR, loopmediated isothermal amplification, etc., will be helpful for detection of this virus. Despite the development of nucleotide sequence-based detection methods, ELISA remains highly relevant for large-scale identification of grapevine virus. Currently, expressing recombinant proteins from cloned virus genes in Escherichia coli is used to produce virus-specific antisera against GVB (Saldarelli and Minafra, 2000; Saldarelli et al., 2005; Radaelli et al., 2008). Thus, to produce antibodies with adequate sensitivity and specificity, better quality antisera obtained against recombinant proteins is necessary. In addition to enhancement of a reliable virus disease diagnosis in grapevines from vineyards, indexing materials from virusfree clone production programs is also important.

Acknowledgements. This research was supported by the China Agriculture Research System No. CARS-30-bc-3 and the Special Fund for Agro-scientific Research in the Public Interest.

Table 1. The nucleotide and amino acid identities (\%) of partial ORF3, ORF4, intergenic region, and partial ORF 5 of variants of GVB isolates from this study with other previously reported isolates

\begin{tabular}{|c|c|c|c|c|c|c|c|c|}
\hline \multirow[b]{2}{*}{ Isolates } & \multicolumn{5}{|c|}{ Nucleotide } & \multicolumn{3}{|c|}{ Amino acid } \\
\hline & $\begin{array}{c}\text { Total } \\
(6408-7129)\end{array}$ & $\begin{array}{c}\text { ORF3 } \\
(6408-6524) \\
\end{array}$ & $\begin{array}{c}\text { ORF4 } \\
(6445-7038) \\
\end{array}$ & $\begin{array}{c}\text { IR } \\
(7039-7079) \\
\end{array}$ & $\begin{array}{c}\text { ORF5 } \\
(7080-7129) \\
\end{array}$ & $\begin{array}{c}\text { ORF3 } \\
(38) \\
\end{array}$ & $\begin{array}{l}\text { ORF4 } \\
(197) \\
\end{array}$ & $\begin{array}{c}\text { ORF5 } \\
(16) \\
\end{array}$ \\
\hline DGWH & 79.1-82.4 & 76.9-83.8 & 77.4-81.1 & 70.7-82.9 & $92.0-100.0$ & $52.6-71.1$ & $89.8-91.4$ & $87.5-100.0$ \\
\hline DGW & $81.2-98.5$ & $82.1-100.0$ & $80.1-98.3$ & $78.0-97.6$ & $90.0-100.0$ & $63.2-100.0$ & $95.9-99.0$ & $87.5-100.0$ \\
\hline QM & $80.2-83.1$ & $83.8-88.0$ & $79.0-82.2$ & $68.3-85.4$ & $90.0-98.0$ & $68.4-76.3$ & $92.9-95.9$ & $93.8-100.0$ \\
\hline JFL & $79.2-82.1$ & $76.9-84.6$ & $77.8-80.8$ & $73.2-80.5$ & $92.0-98.0$ & $52.6-71.1$ & $88.8-91.4$ & $93.8-100.0$ \\
\hline QMW & $79.4-83.2$ & 82.1-88.9 & $78.8-82.2$ & $68.3-85.4$ & $90.0-100.0$ & $65.8-78.9$ & $90.4-94.9$ & $93.8-100.0$ \\
\hline G-B & $79.5-98.5$ & $76.9-100.0$ & 78.1-98.5 & 75.6-97.6 & $84.0-100.0$ & $52.6-100.0$ & $90.9-99.0$ & $68.6-100.0$ \\
\hline
\end{tabular}

The sequence data presented in this paper have been submitted to the GenBank nucleotide sequence database and have been assigned Acc. Nos KC861195KC861225. The identities of nucleotides and amino acids in this Table represent the identity range of all variants of each isolate with the previously published GVB isolates. The GenBank Acc. Nos of previously reported isolates are EF583906 (South African), GU733707 (South African), GU984638 (South African), JX513897 (USA), and X75448 (Italy). 
(a)

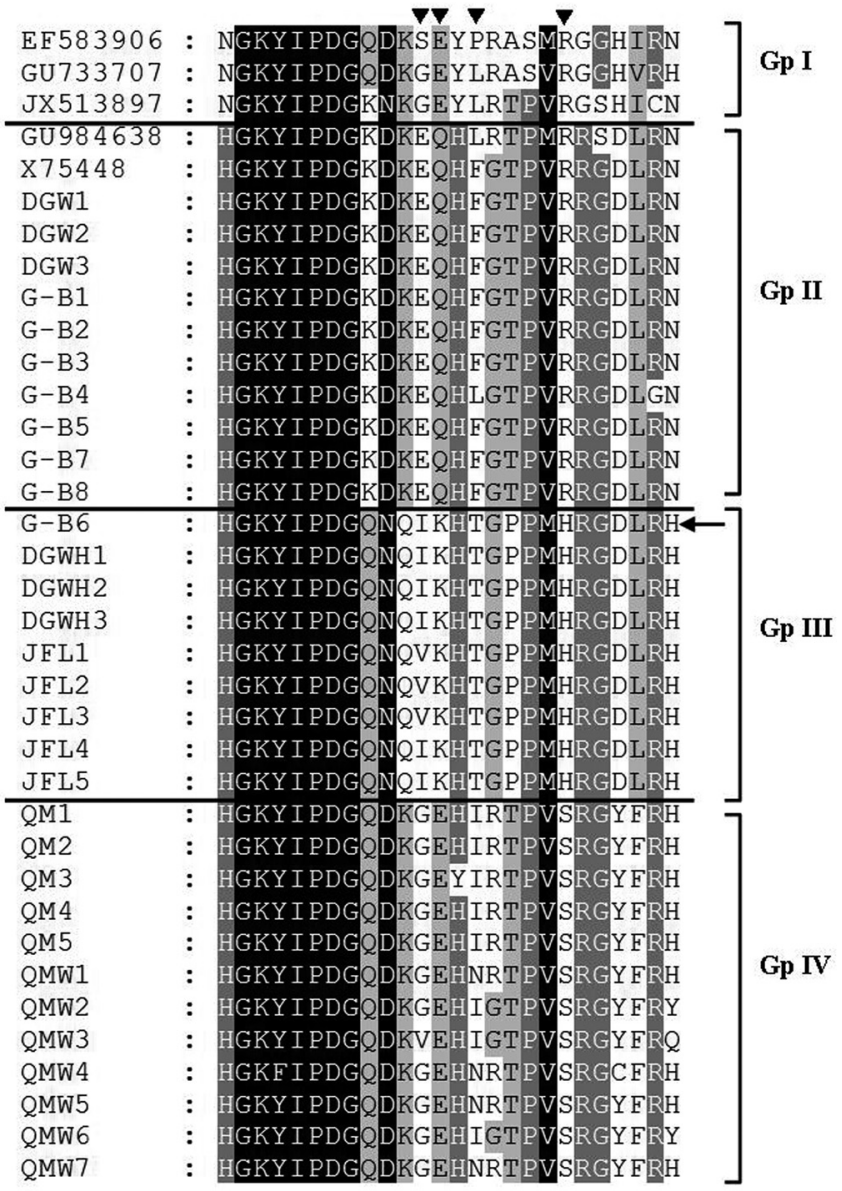

(b)

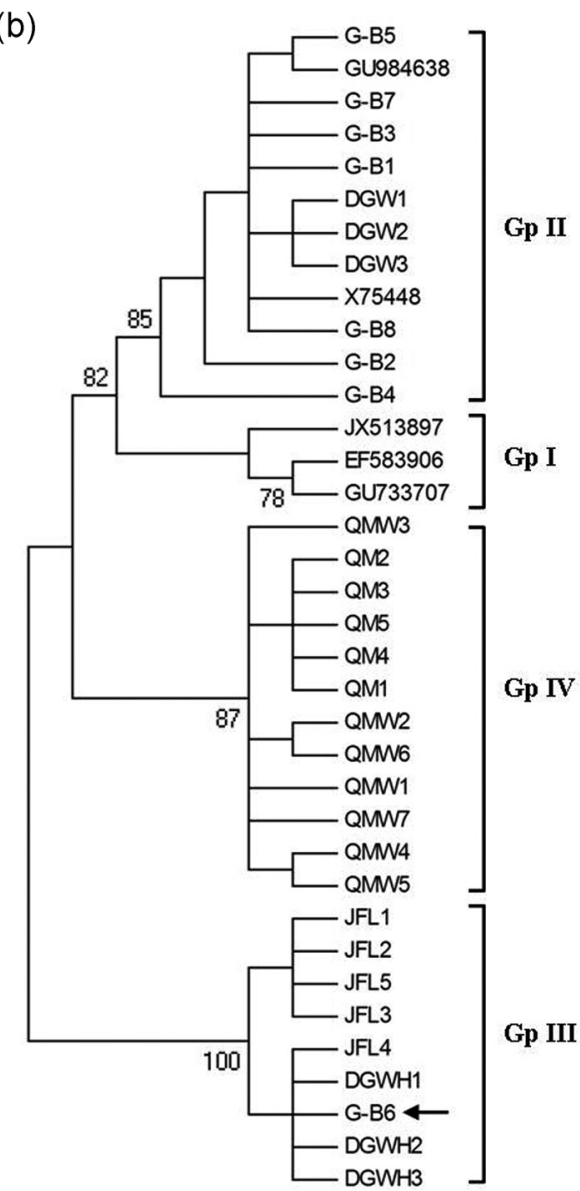

Fig. 1

Alignment of partial amino acid sequence encoded by ORF3 (a) and phylogenetic analysis of amino acid sequences of the ORF4 (b) from variants of Chinese GVB isolates and isolates available in GenBank

Nodes bearing $<75 \%$ bootstrap values support collapse to polytomies. Branch lengths corresponding to the genetic distances are indicated on the scale bar. Four special amino acids in (A) are marked by " $\nabla$ ". Variant G-B is marked by an arrow.

\section{References}

Boscia D, Savino V, Minafra A, Namba S, Elicio V, Castellano MA, Gonsalves D, Martelli GP (1993): Properties of a filamentous virus isolated from grapevines affected by corky bark. Arch. Virol. 130, 109-120. http://dx.doi. org/10.1007/BF01319000

Boscia D, Minafra A, Martelli GP (1997): Filamentous viruses of the grapevine: putative trichoviruses and capilloviruses. In Monette PL (Eds): Filamentous Viruses of Woody Plants. Research Signpost, Trivandrum, India, pp. 19-28.

Chiba M, Reed JC, Prokhnevsky AI, Chapman EJ, Mawassi M, Koonin EV, Carrington JC, Dolja VV (2006): Diverse suppressors of RNA silencing enhance agroinfection by a viral replicon. Virology $346,7-14$. http://dx.doi. org/10.1016/j.virol.2005.09.068

Engelbrecht DJ, Kasdorf GGF (1990): Field spread of corky bark, fleck, leafroll and Shiraz decline diseases and associated viruses in South African grapevines. Phytophylactica 22, 347-354.

Foissac X, Svanella-Dumas L, Dulucq MJ, Candresse T, Gentit P (2001): Polyvalent detection of fruit tree tricho, capillo and foveaviruses by nested RT-PCR using degenerated and inosine containing primers (PDO RT-PCR). Acta Hort. 550, 37-44.

Garau R, Prota V, Boscia D, Fiori M Prota U (1995): Pseudococcus affinis Mask., a new vector of grapevine trichoviruses A and B. Vitis 34, 67-68.

Garau R, Prota V, Boscia D, Piredda R, Prota U (1993): Studies on Grapevine virus B isolates from corky bark-affected vines in Sardinia. Riv. Patol. Veg. S3, 83-89.

Golino DA, Sim S T, Rowhani A (1995): Transmission studies of grapevine leafroll associated virus and grapevine corky bark associated virus by the obscure mealybug. Am. J. Enol. Vitic. 46, 408.

Goszczynski DE (2010): Divergent molecular variants of Grapevine virus $B(G V B)$ from corky bark $(\mathrm{CB})$-affected and 
CB-negative LN33 hybrid grapevines. Virus genes 41, 273-281. http://dx.doi.org/10.1007/s11262-010-0511-6

Haviv S, Moskovitz Y, Mawassi M (2012): The ORF3-encoded proteins of vitiviruses GVA and GVB induce tubule-like and punctate structures during virus infection and localize to the plasmodesmata. Virus Res. 163, 291-301. http:// dx.doi.org/10.1016/i.virusres.2011.10.015

Hewitt WB (1954): Some virus and virus-like diseases of grapevine. California Dept. Agr. Bul. 43, 47-64.

Liu X, Boscia D, Raimondi T, Broggio M, Chen J, Li H, Wang JH, Liu JJ (2004): Field investigation and serological detection of grapevine viruses in Sichuan province. Southwest China J. Agri. Sci. 17, 52-56.

Liu YQ, Wang GP (2004): Techniques for detecting grapevine virus. Sino-overseas Grapevine \& Wine 4, 27-28.

Magome H, Yoshikawa N, Takahashi T (1999): Single-strand conformation polymorphism analysis of Apple stem grooving capillovirus sequence variants. Phytopathology 89, 136140. http://dx.doi.org/10.1094/PHYTO.1999.89.2.136

Komínek P, Glasa M, Komínková M (2009): Analysis of multiple virus-infected grapevine plant reveals persistence but uneven virus distribution. Acta Virol. 53, 281-285. http:// dx.doi.org/10.4149/av 200904281

Moskovitz Y, Goszczynski DE, Bir L, Fingstein A, Czosnek H, Mawassi M (2008): Sequencing and assembly of a full-length infectious clone of Grapevine virus B and its infectivity on herbaceous plants. Arch. Virol. 153, 323-328. http:// dx.doi.org/10.1007/s00705-007-1075-1

Radaelli P, Fajardo TVM, Nickel O, Eiras M, Pio-Ribeiro G (2008): Production of polyclonal antisera using recombinant coat proteins of Grapevine leafroll-associated virus
2 and Grapevine virus B. Pesquisa Agropecu. Bras. 43, 1405-1411. http://dx.doi.org/10.1590/S0100204X2008001000020

Saldarelli P, Dell'Orco M, Minafra A (2000): Infectious cDNA clones of two grapevine viruses. Arch. Virol. 145, 397-405. http://dx.doi.org/10.1007/s007050050031

Saldarelli P, Keller HHG, Dell'Orco M, Schots A, Elicio V, Minafra A (2005): Isolation of recombinant antibodies (scFvs) to Grapevine virus B. J. Virol. Methods 124, 191-195. http:// dx.doi.org/10.1016/j.jviromet.2004.11.021

Saldarelli P, Minafra A (2000): Immunodetection of the $20 \mathrm{kDa}$ protein encoded by ORF 2 of Grapevine virus B. J. Plant Pathol. 82, 157-158.

Saldarelli P, Minafra A, Martelli GP (1996): The nucleotide sequence and genome organization of Grapevine virus B. J. Gen. Virol. 77, 2645-2652. http://dx.doi.org/10.1099/0022$\underline{1317-77-10-2645}$

Sciancalepore A, Pio Ribeiro G, Turturo C, Dell'Orco M, Minafra A, Saldarelli P, Martelli GP (2006): Molecular variability of GVA and GVB coat protein genes in naturally infected grapevine accessions. In Extended abstracts of the 15th Meeting of ICVG, Stellenbosch, pp. 81-82.

Shi BJ, Habili N, Gafny R, Symons RH (2004): Extensive variation of sequence within isolates of Grapevine virus B. Virus Genes 29, 279-285. http://dx.doi.org/10.1023/ B:VIRU.0000036388.41242.c1

Zhou ZS, Dell'Orco M, Saldarelli P, Turturo C, Minafra A, Martelli GP (2006): Identification of an RNA-silencing suppressor in the genome of Grapevine virus A. J. Gen. Virol. 87, 2387-2395. http://dx.doi.org/10.1099/vir.0.81893-0 